\title{
Ubiquitous Learning Environment for Smart Improving Disruption Activities in Classroom on Media
}

https://doi.org/10.3991/ijim.v14i13.15609

\author{
Muhammad Ashar ${ }^{(凶)}$, Harits Ar Rosyid, \\ Agusta Rahmat Taufani, Khaidir Rahman N \\ Universitas Negeri Malang, Malang, Indonesia \\ muhammad.ashar.fteum.ac.id
}

\begin{abstract}
Smart learning emphasizes the educational needs of students learning to grow smarter as a result of an intelligent environment. Universities should have the right strategy through the utilization of limited resources, especially with regard to human resources. Objective research offers the benefits of learning in the form of influence over these resources are limited and focused on the use of online learning to support learning through class room facility improvements with a medium of learning through virtual environments and utilize technology and multimedia content adaptive cameras in some areas. The research method using descriptive experimental method in the fifth stage of design and product development of mobile applications in the form of a waterfall model through a needs analysis devices and digital facilities
\end{abstract}

Keywords - Ubiquitous learning, Impaired Media, Camera Sensor, Multimed ia, Mobile Apps.

\section{$1 \quad$ Introduction}

A new paradigm of traditional learning methods to learn everywhere that makes us capable of without bringing the system to obtain data everywhere, anytime with the necessary means. customized learning technology in the education system can be called the E-learning has replaced the books and the use of the board. M- learning allows access to information, anywhere and U-learning provides unlimited transmission of information in the right way, anytime, anywhere. Third-learning technology certainly has different features and the use of U-learning though the cost of installing the system u-learning are high, after a very cost-effective implementation [1]. The use of learning everywhere on campus in Indonesia has not been widely used in support of online and blended learning [2]. But the development of the concepts learned MOOC use everywhere will require a shift in technology and the use of media with disruptive technologies will require the use of learning everywhere to be the right choice [3].

Learning everywhere refers to the likelihood that a person involved in a learning situation which is not bound by time or classrooms, [4]. Some argue that the omnipresence and the availability of online access will further enhance the digital gap between skilled and unskilled users, as well as between rich and poor, [5]. Others 
argued that students who have online access throughout the day tend to develop bad study habits because they tend to move their attention away from the classroom, [6]. Such as freedom of opportunistic and potential functions to access information and elearning programs also contribute in reducing the continuum between formal education and informal learning, [7].

Is the use of e-learning is seen as online learning facilities and resources in a virtual environment and easy access to both the content of learning services, media, network facilities, and good interaction with the information system between faculty and students, [8]. Using Room U-Class will make digital learning in the classroom leading to a more optimal system and service management Education, [9]. However, by utilizing various technological components such as hardware, software, netware, infoware, etc., through access devices such as computers, gadgets, slate digital, notebooks, and mobile phones, students can freely and smoothly implement learning activities freely and independently, without being limited by space and time, [10].

Although the student will generally prefer to use mobile technology, in principle, ulearning technologies allow students to use various technologies available on the market, Bill Cope and Mary Kalantzis. It should be noted that in the technology used, "implanted" a number of smart applications are referred to as u-learning agency, to facilitate students in acquiring the information and knowledge that is relevant to their needs. This application is said to have the intelligence because it serves to study the characteristics of student learning.

This study focuses on the use of learning everywhere to support online learning in the State University of Malang through facility improvements class rooms with a medium of learning through technology virtual environments and utilize digital media books, posters, digital board, 360 cameras and multimedia content in a number areas such as classrooms, laboratories, library cafes, libraries, museums and parks on campus.

By implementing mobile applications, smartphones, sensors, cameras and laptops (notebooks) with integrated online learning system (Sipejar). Room service U-calc with this integration synergies intelligent learning, pedagogy smart and intelligent environments through a platform created to be monitored in a multi access to all online learning on campus.

The purpose of this research is to develop digital technology in assisting the learning process online (online courses) at the State University of Malang. The purpose of this study is how the process of online learning in the classroom and outside the classroom can be integrated through the Internet (ICT) by utilizing the media everywhere intrusive infrastructure to optimize the learning environment cerdasuntuk acquire learning management effective and efficient in the future.

\section{$2 \quad$ Literature Review}

This section presents several theoretical concepts that support the Smart ubiquitous learning environment to enhance classroom activities in media in Indonesia. The concepts include the problem of mobile applications, smartphone devices, sensors, cameras and laptops (notebooks) that are integrated with the online learning system 
(siPejar). U-calc room service with this integration results in a synergy of smart learning, smart pedagogy, and intelligent environment through a platform that is monitored in multi-access to all online learning on campus. These problems can be described as follows.

\subsection{Ubiquitous computing}

The term ubiquitous computing, as coined by Mark Weiser, refers to the process of seamlessly integrating computers into the physical world. As a researcher at Xerox PARC, he described in the late 80 s and the early 90 s his vision for the next generation of computing. He pointed out, that "the most profound technologies are those that disappear. They weave themselves into the fabric of everyday life until they are indistinguishable from it." The desktop computer will be replaced by computing embedded in physical objects of everyday life, by which these are not detracted from their original functionality but enhanced by computing. Besides this kind of physical disappearance, ubiquitous computing also comprises mentally disappearance. In the latter case computers can still be there but the user perceives them as, for example, interactive walls or interactive tables [37], or still as laptops, personal digital devices like the electronic whiteboard, palm pilot, digital cameras, mobile phones, PDAs, etc. Many research and industry groups are engaged in ubiquitous computing, each focusing on special aspects. Over the years slightly different definitions of ubiquitous computing arise emphasizing selected aspects, e.g., technical infrastructure and/or context awareness. Notions like pervasive computing, proactive computing and ambient computing are introduced to stress the particular direction of a work and project, respectively, but are also used synonymously with 'ubiquitous computing'. Regardless of the term used, research focus is on the disappearing artefact, and the environment and situation within which people experience it. Like, for example, in the case of driving a car, where mentally and physically the engine disappears. People simply drive the vehicle to a destination, considering the way to reach it and the physical environment - but normally not thinking about the engine itself, how it works or is constructed. Similarly, people don't need computing at all - they need the information, functions and services to perform their tasks. This is not a totally new issue in computing, e.g., the desktop metaphor and the concept of direct manipulation [38] were introduced to excuse the user from paying too much attention to technical aspects - the desktop computer, however, remains in the foreground. With the disappearing computer, but ubiquity of computing, supporting the user with the right information and services at the right time and place in the right way is a new, far more challenging and complex issue than in the case of traditional applications.

\subsection{Ubiquitous web applications}

The development of ubiquitous web applications involves adaptation not only to different kinds of devices, but also to, e.g., network, location and time. [29], for instance, proposed a framework, within which the generic model for describing contexts is divided into a physical and a logical model. The physical context model 
specifies characteristics being outside of the control of ubiquitous web applications, i.e., characteristics which cannot be affected by adaptation. This model comprises properties of location, time, device, browser, network, and the user. The logical context model is defined by enriching the semantics of the physical model for the purpose of customization. While, for example, locations within a physical context model may be described by cell IDs, they may be described in the logical context model by postal addresses. The context model also describes information about an application itself as its states may influence adaptation. If the completion of a task, for example, is not successful this may constrain subsequent execution of further tasks. The part of the model related to the application dependent aspects is not elaborated in (Kappel et al. 2002), thus the proposed framework has to be expanded by the application relevant context descriptions. These supplementations cannot be specified generally for all ubiquitious learning applications since the diverse kinds of learning systems impose different requirements on adaptation (see also Ahonen, [30].

\subsection{Adaptive and intelligent web-based educational systems}

Adaptation in the field of e-learning has been investigated for decades. As pointed out, [31], adaptive and intelligent web based educational systems "attempt to be more adaptive by building a model of the goals, preferences and knowledge of each individual student and using this model throughout the interaction with the student in order to adapt to the needs of that student. They also attempt to be more intelligent by incorporating and performing some activities traditionally executed by a human teacher - such as coaching students or diagnosing their misconceptions." Hereby, adaptive educational systems, which deal with adaptive presentation and navigation, are integrated with intelligent educational systems, which focus on curriculum sequencing to guide the learner through the digital learning space (hyperspace), intelligent solution analysis dealing with the learners' solution of educational problems, and problem solving support interactively providing the learners with help on each step of problem solving. In those systems the digital learning space is adapted to the learners, i.e., each individual student is provided with his personal digital learning space, under the tacit assumption that all students access the space by means of a standard browser running on a PC. With the increasing spread of mobile and wireless devices adaptation has to overcome this limitation. Doing so, more characteristics of the environment than only the properties of the devices have to be considered.

\subsection{Critical thinking skills}

The use of learning which supports online learning which reflects 21 st century learning skills. As stated in [32], through virtual environment technology and utilizing digital media. Furthermore, Kim et al. [33] argue that mobile applications involve students to produce synergies of intelligent learning in ways that are purposeful, reasonable, evaluative, and reflective in the learning process everywhere. In the context of digital applications and teaching in learning skills where - where needed to encourage pre lecturers to think highly. This helps them to learn effectively and accurately. 
Nevertheless, much research in higher education has found that lecturers and teachers lack in-depth knowledge and understanding of intelligent learning skills about how they are into online learning so students can develop their potential from them [34] [35] [35].

\section{$3 \quad$ Method}

This study used an experimental method descriptive through the stages of design and product development of digital books to software engineering waterfall model. Needs analysis devices and facilities of digital books including application software and hardware, design and manufacturing of the service system of digital books multiple access with implementation to integrate the principles of instructional media design according intelligent, interactive, educational theory, experiment and media and system validation of results implementation of any part of the system until enough results obtained for testing in a campus environment, [11]. The study was conducted in Univerisitas Malang in the classroom and outside the classroom, all the students involved in this trial. The results of this experiment will be evaluated to revise the system that have not been optimized through changes in the implementation of the code with the modification of the previous design. The testing process will be obtained by media digital book application that has been integrated with intelligent learning system monitoring (activity everywhere intelligent) and natural language that is ready to be produced and patented.

Development of the system U-Class Room of learning platforms everywhere as smart environments campus for self-learning online requires an adequate infrastructure and complete through the process of designing and creating self-learning system that is equipped with a system activity condition monitoring (smart sensor) for users to display content and learning activities well and have a material suitable for users (students and faculty) in a live program Based learning, [12]. Where the results of this experiment will be evaluated to revise the system that have not been optimized through changes in the implementation of the code with the modification of the previous design. The testing process will be obtained by using the media application on the device everywhere or android smartphone which has been integrated with intelligent learning system (activity everywhere clever).

\section{$4 \quad$ Research Finding and Discussion}

\subsection{Research findings}

This process is performed on the sensor system comera grade classrooms by utilizing CCTV or Camera Mobile and Digital Camera connected via Wifi Network is located in an upscale area. Next is a sensor system design canera Classroom in Figure 1. 


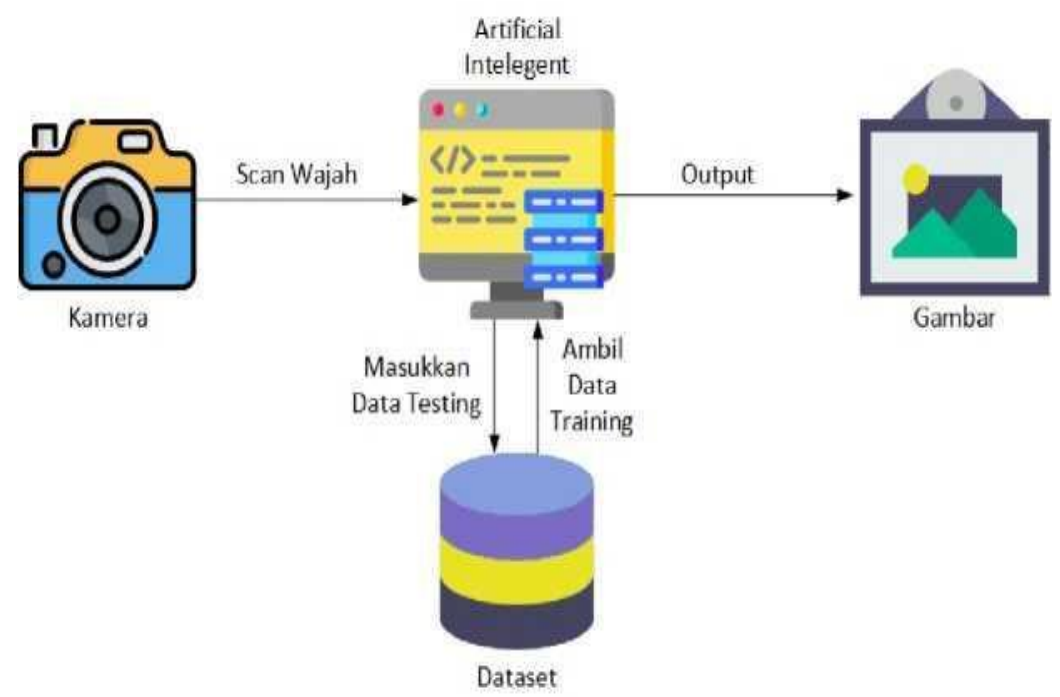

Fig. 1. Camera Sensor Framework in the Classroom

The function was developed in this system is checked by the camera sensor's ability to detect and record student activity via expression captured by a camera and send it to the cluster data everywhere in determining changes in materials or instructional content automatically based on the system through the following steps:

- Input Stage: Put on a face detection system is a camera (webcam) that will capture its expression (Streaming). Phase Process: In the process of facial expression detection system, the program implements the AI (Artificial Intelligence) which expression studies that have been provided in the dataset. The algorithm used is Convolutional Neural Network (CNN).

- Stage Output: Output is in the form of a folder containing the greyscale image of expression of users who previously have been labeled in the form of a .jpg with $48 \times 48$ pixel and output.txt file that contains the expression was detected. The following discussion of the algorithms performed on this system are:

1. Own face detection using Haar Cascade Classifier classification algorithm previously trained. Then the detected faces will be classified.

2. In Artificial Intelligence, which conduct training program using a process 28,000 data and testing with 3000 data. Training data and test data in the form of pixels of the image of a face in the form of 48x 48 grayscale images or as much as 2304 pixels in each picture. Training is done to adjust the weights in Neural Networks to classify facial expressions that go through Input.

3. Put on a laptop using a webcam to capture images in real time which is then converted into a $48 \times 48$ pixel grayscale image then the image can be input via Neural Networks. 
4. The program will automatically determine the faces and expressions are displayed based on the classification made in the training process data.

5. Next, the output is issued in the form of a directory folder that contains photo files as a result of the detection of the expression. Whenever there is a change in expression or detecting a new expression, it will be saved by capturing only the face and the dimensions of $48 \times 48$ pixel and grayscale images. At the same time a text file that displays the type of expression appear.

6. The program is run by a python script execution. It will display the camera interface and tag faces.

7. The program then accesses the laptop camera detects faces and expressions.

A number of studies [13], [14], and [15] focused solely on the technological aspects to conduct investigations as various physical equipment used in their research. The use of sensors to control the room temperature while the camera, projector and big screen trash class to create technology-heavy environment. Several other researchers, [16], [17] and [18]. Inoue focused only on special equipment because they develop high technology and student table virtual projection to create a full class ambient around educator.

The results of the application of the camera sensor indicates the ability of the algorithm to detect individually (single face) and can also detect multi-person (multiface) with the correlation of the correlation of natural and shows real-time truth of the average $93 \%$, while showing experimental artificial truth value lowered by $88 \%$ indicates that the value of truth have met the standard identification of facial expressions is naturally more accurate.
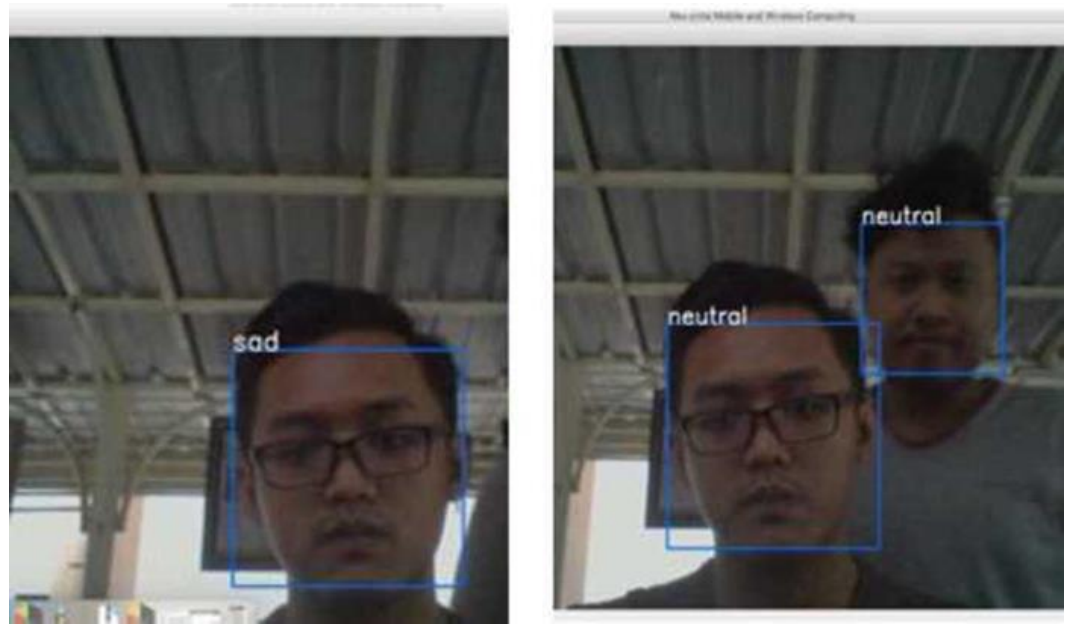

Fig. 2. (left) single facial expression detection, (right) multiface expression detection sensor Using the camera in a classroom 


\subsection{Discussion}

In the process of using ICT access the Internet via wireless networks everywhere (wifi behavior, wifi AP) used for the system on the priority subjects of high priority. Direct recommendation system using the connection classrooms on each smartphone users (students) showed that the content be priositas differ from one another in the form of a number of the Court or the Materials, and Materials Sub or supplement teaching materials. The algorithm was developed by combining Artificial Ubiquitous with Personalized Data specialties current state (real-time) which provide results that each student can learn independently select the media or content according to their desire to learn with the media who choose or content created using Android-based applications. From this work can provide application or media content recommendation through a selection process after filling in questionnaires users of the application. There are three features that appear, in which the first feature in the form of information will be a question and answer.

The second feature is the emergence of the process, in the sense that the questions that have been answered will be processed using a SAW (Simple Additive weighting) algorithm where the algorithm is an algorithm in the decision making in choosing elective courses that require a normalization process decisions and then the results of normalization will be compared with scale response thus giving a final decision. the scale of the total value derived from the user's selection of answers to questions and answers $(\mathrm{Q} / \mathrm{A})$ is the accumulation and the decision of the AI network is constructed through modification algorithm SAW. The end result has the largest scale value according Answer (A) of the questions answered on the sheet Question (Q) of the screen questions. In accordance with the selected answer in the above screen is Open Source technology with value scale 18 points. Thus, the course will be selected is the Open Source Technology. In accordance with the selected answer in the above screen is Open Source technology with value scale 18 points. Thus, the course will be selected is the Open Source Technology. In accordance with the selected answer in the above screen is Open Source technology with value scale 18 points. Thus, the course will be selected is the Open Source Technology. which of course will be selected is the Open Source Technology. In accordance with the selected answer in the above screen is Open Source technology with value scale 18 points. Thus, the course will be selected is the Open Source Technology. which of course will be selected is the Open Source Technology. In accordance with the selected answer in the above screen is Open Source technology with value scale 18 points. Thus, the course will be selected is the Open Source Technology. 


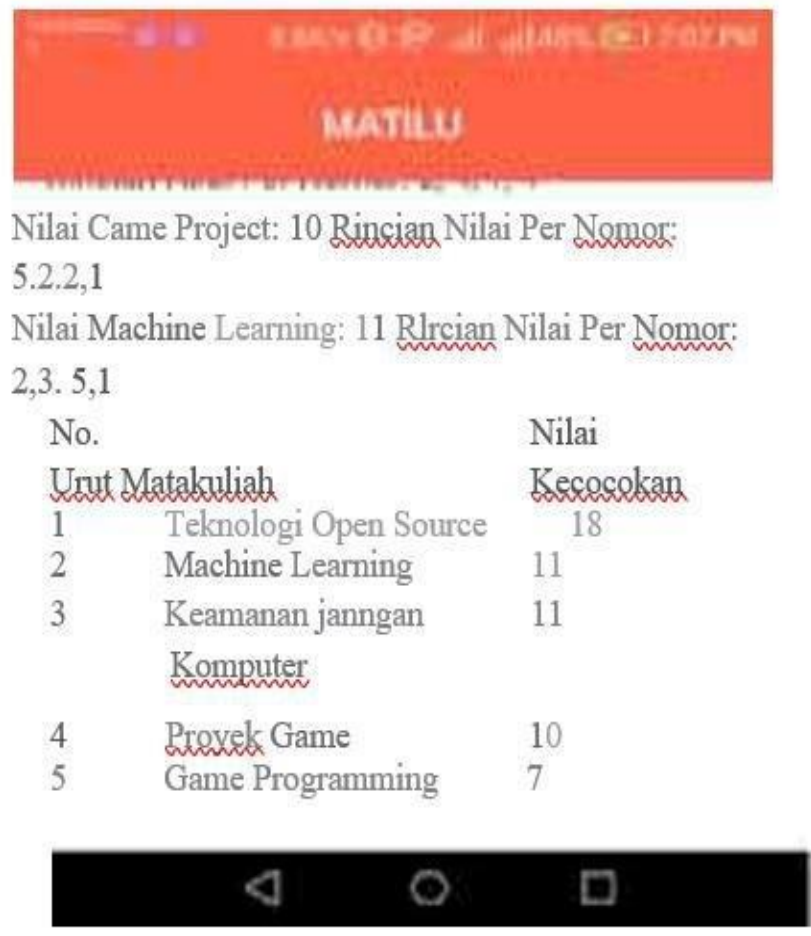

Fig. 3. Priority Content matching Based Q/A

Wireless technology also fell in parts of the technological aspects which concern other research projectsC. [19] and [20], RFID (Radio Frequency ID) and NFC (Near Field Communication) Media that is widely used to identify individual learners and educators in an effort to tailor the service, as well as perform additional functions. Very few research projectsA. [21], and [22] is regarded as the educational aspects of learner profile and content management issues are considered, while none of the projects reviewed in the literature focused on the social dimension. Aspects of technology, education and social services all require attention because if proper investigation to be carried out where a complete and realistic effort of intelligent learning environment is to be developed. (23), (24).

Furthermore, to identify the purpose of transferring the data so that each can carry out accurate data delivery, content exchange, and the type of media used, the creation and setting the IP address is needed in priority traffic. [25], [26], In this system, the transfer of data sharing using an ad hoc wireless network (everywhere) data or content can be transferred in real time according to the personal data connection and facial expressions. However, this system cannot be achieved optimally so that the need to process or stage integration and testing experts and widely to potential customers. As Figure 3shows the results share data (transfer of multimedia data such as images, text, audio and video), [27], [28]. 


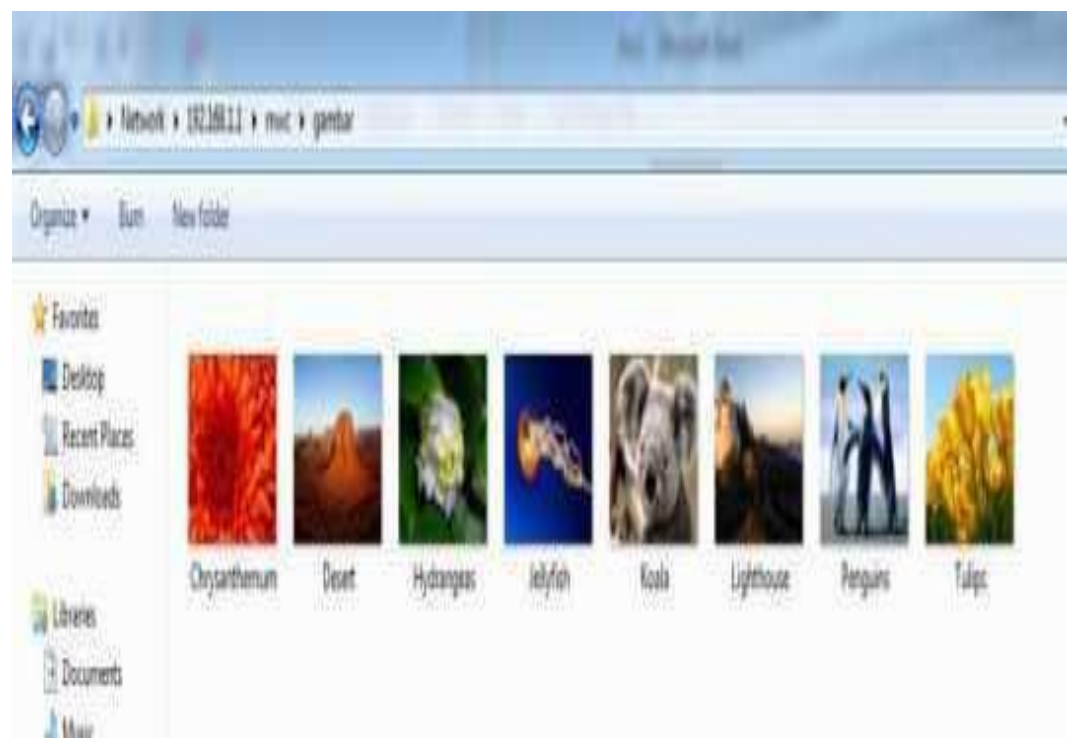

Fig. 4. Multimedia Personal Data Sharing Using Local Wireless Network based on their facial expressions and Priorities Content Matching

\section{Conclusion}

In this paper, we have presented the three main important standpoints of our research related to ubiquitous smart learning environments. Initially the concept of smart environments was applied and justified within an academic situation. However, we strongly argued that in order to effectively realise such a project in a correct and accurate way, three aspects are required to be thoroughly investigated and applied. The social aspect is imperative due to the communal presence of students and teacher within the classroom, physical or virtual. Secondly, the technological aspect is also very important due to the crucial role that various instruments play within a high-tech classroom as specific functionalities are required, as well as, data is needs to be collected. Finally, the educational aspect is central for obvious reasons. In this case we related this aspect to the use of seven e-learning affordances upon which the virtual learning environment is based upon.

The utilization of classrooms everywhere has advantages in supporting online learning and teaching process by producing function (1) Develop a media that disrupt learning through intelligent algorithms to assist the learning process more intelligent optimal, (2). Achieving experimental capabilities and the application of ICT-based science education with smart device technology innovation disruotive learning, (3). Produce learning product innovation with the potential large-scale development through the media interfere.

This study used an experimental method descriptive through the stages of design and product development of digital books to software engineering waterfall model. Needs 
analysis devices and facilities of digital books including application software and hardware, design and manufacturing of the service system of digital books multiple access with implementation to integrate the principles of instructional media design according intelligent, interactive, educational theory, experiment and media and system validation of results implementation of any part of the system until enough results obtained for testing in a campus environment.

\section{References}

[1] Saraswati Mishra, Meenakshi Yadav, Kavita Choudhary, belajar Ubiquitous: Masa Depan e-Learning Konferensi: Konferensi Internasional Pertama tentang muncul tren Teknik dan Ilmu Pengetahuan Terapan Pada: Jaipur Volume: Konferensi proceding, Desember 2013

[2] Indrajit, Membangun Ekosistem Ubiquitous Learning di Inonesia, Sebuah Usulan Kerangka strategis, Universitas Negeri Malang Press, 2016

[3] Wiley, DA (2000). Menghubungkan Belajar Objects untuk Teori Desain Instruksional: Definisi, sebuah Methaphore, dan Taksonomi.

[4] M. Twindale, "Dari Ubiquitous Computing untuk Ubiquitous Learning," di mana-mana Learning, Champaign, Illinois, University of Illinois, 2009.

[5] EN Asiimwe dan SZ Khan, "Ubiquitous Computing dalam Pendidikan: Sebuah Analisis SWOT oleh Mahasiswa dan Guru," di 12 Konferensi Dunia tentang Mobile dan Pembelajaran Kontekstual (mLearn 2013), Qatar, 2013.

[6] S.-W. Hsieh, Y.-R. Jang, G.-J. Hwang dan N.-S. Chen, "Efek dari pengajaran dan gaya pada tingkat refleksi siswa untuk belajar di mana-mana, belajar" Komputer \& Pendidikan, vol. 57, tidak ada. 1, pp. 1194-1201, 2011. https://doi.org/10.23887/jppundiksha.v49i3. $\underline{9015}$

[7] S. Yahya, E. Ahmad dan K. Abd Jalil, "Definisi dan karakteristik pembelajaran di manamana: A diskusi," International Journal of Education and Development using Information dan Teknologi komunikasi (IJEDICT), vol. 6, tidak ada. 1, pp. 117-127 2010.

[8] Yu, S. et al. (2014). Dari Belajar Obyek Belajar Sel: Sebuah Sumber Daya Model Organisasi untuk UbiquitousLearning. Teknologi Pendidikan \& Society, 18 (2), 206-224.

[9] Oliver, B., \& Liber, O. (2011). Lifelong Learning: Kebutuhan Portable Personal Learning Environments Standar Interoperabilitas andSupporting.

[10] Ribas, E. et al. (2015). Technologieas Digitais. Um Novo contexto Pedagogico na Educação Basica.Colabora, Fevereiro.

[11] Cearley, DW (2010). Cloud Computing: Key Initiative. 2010 GartnerInitiative.

[12] B, ertram C. Bruce, Ubiquitous Learning, Ubiquitous Computing, dan pengalaman hidup, Prosiding Konferensi Internasional ke-6 pada Jaringan Belajar ISBN No: 978-1-86220-206$1 \backslash$

[13] L. Winer dan J. Cooperstock, "The "Cerdas Kelas": mengubah pengajaran dan pembelajaran dengan lingkungan teknologi yang berkembang," Komputer \& Pendidikan, vol.38, pp 253266, 2002.

[14] R. Ramadhan, H. Hagras, M. Nawito, A. Faham dan B. Eldesouky, "The Intelligent Kelas: Menuju Intelijen Testbed Pendidikan Ambient," di 6 Konferensi Internasional tentang Enviroments Cerdas 2010.

[15] P. Santana-Mancilla, M. Echeverrie, J. Santos, J. Castellanos dan A. Diaz, "Menuju Pendidikan Cerdas: Ambient Intelligence di Meksiko Ruang Kelas," Sosial dan Behaviousal Ilmu, vol. 106, pp. 3141-3148, 2013. 
[16] Shen, Y. Wu dan T. Lee, "Mengembangkan kelas pintar NFC-dilengkapi: Efek pada sikap terhadap ilmu komputer," Komputer di Human Behavior, vol. 30, pp.731-738 2014.

[17] M. Antona, G. Margetis, S. Ntoa, A. Leonidis, M. korozi, G. Paparoulis dan C. Stephanidis, "Ambient Intelligence di Kelas: sebuah meja Augmented School," dalam 3 Konferensi Internasional pada Faktor Terapan Manusia dan Ergonomi, Miami 2010. https://doi.org/10.1201/ebk1439835036-68

[18] T. Tagawa, N. Fujimura, S. Hasikura dan H. Inoue, "Pengantar dan pengelolaan kampus antar pembelajaran asisten sistem kampus didistribusikan," di 37 SIGUCCS ACM tahunan konferensi, New York, 2009 jatuh.

[19] Leonidis, G. Margetis, M. Antona dan C. Stephanidis, "Classmate: Mengaktifkan Ambient Intelligence di Kelas," International Journal of Computer, Electrical, Automation, Control dan Teknik Informatika, vol. 4, tidak ada. 6, pp. 1058-1061, 2010.

[20] Bill Cope \& Mary Kalantzis, Ubiquitous Learning: Sebuah Agenda untuk Transformasi Pendidikan, prosiding Konferensi Internasional 6 pada Jaringan Belajar, ISBN No: 978-186220206-1

[21] Byun, HE (2004). Memanfaatkan Konteks Sejarah Menyediakan Dinamis Adaptasi. Terapan Artificial Intelligence, Volume 18 (6), 533-548.

[22] Franco, CP (2010). Sebuah Platforma Moodle como Alternativa para uma Educação Flexivel. Dalam Revista EducaOnline Volume 4-Numero 1.

[23] M. Twindale, "Dari Ubiquitous Computing untuk Ubiquitous Learning," di mana-mana Learning, Champaign, Illinois, University of Illinois, 2009.

[24] Soror, AA et al. (2010). Otomatis Virtual Machine konfigurasi untuk database Beban Kerja. ACM Trans Sistem Database, 35 (1), 1-47.

[25] Wiley, DA (2000). Menghubungkan Belajar Objects untuk Teori Desain Instruksional: Definisi, sebuah Methaphore, dan Taksonomi.

[26] Y. Shi, W. Xie, G. Xu, R. Shi, E. Chen, Y. Mao dan F. Liu, “Smart Kelas: Penggabungan Teknologi untuk Seamless Tele-Education," Pervasive Computing, vol. 2, tidak ada. 2, pp. 47-55, 2003. https://doi.org/10.1109/mprv.2003.1203753

[27] Haerazi, I Made Permadi Utama, Heri Hidayatullah. (2020). Mobile Applications to Improve English Writing Skills Viewed from Critical Thinking Ability for Pre-Service Teachers. Internasional journal of interactive mobile technologies. https://doi.org/10.3991/ ijim.v14i07.11900.

[28] Junrie B. Matias (2020), Narciso M. Batingal Jr, Alvin Kleen L. Cuasito, Jenifer T. Tumalaytay (2020) Mobile Based Sharing Class Presentation Display Management. Internasional journal of interactive mobile technologies. https://doi.org/10.3991/ijim.v14 $\underline{\mathrm{i} 07.11718}$

[29] Kappel, G.; Retschitzegger, W.; Kimmerstorfer, E.; Pröll, B.; Schwinger, W., Hofer, Th. (2002). Towards a Generic Customization Model for Ubiquitous Web Application In: IWWOST'02 Conference Proceedings. Asa

[30] Ahonen, M.; Syvänen, A.; Vainio, T. (2005) Towards Pervasive and Adaptive Learning Environments, to appear in: Proceedings of the HCI International 2005.

[31] Brusilovsky, P., Peylo, C. (2003). Adaptive and Intelligent Web-based Educational Systems, In: International Journal of Artificial Intelligence in Education 13 (2003, IOS Press, 156169

[32] Lai, E. R. (2011). Critical Thinking: A Literature Review. Research Report. Pearson.

[33] Kim, K., Sharma, P., Land, S. M., \& Furlong, K. P. (2013). Effects of active learning on enhancing student critical thinking in an undergraduate general science course. Innovative Higher Education, 38(3), 223-235. https://doi.org/10.1007/s10755-012-9236-X 
[34] Nold, H. (2017). Using critical thinking teaching methods to increase student success: An action research project. International Journal of Teaching and Learning in Higher Education, 29(1), 17-32. http://www.isetl.org/ijtlhe/

[35] Alwehaibi, H. (2012). Novel program to promote critical thinking among higher education students: Empirical study from Saudi Arabia. Asian Social Science, 8(11), 193-204. https:// doi.org/10.5539/ass.v8n11p193

[36] Chang, C.-Y.; Sheu, J.-P.: Design and Implementation of Ad Hoc Classrroom and eSChoolbad Systems for Ubiquitous Learning. In: Proceedings of the IEEE International Workshop on Wireless and Mobile Technologies in Education, WMTE'02, (2002). https:// doi.org/10.1109/wmte.2002.1039215

[37] Streitz, N.; Nixon, P.: The Disappearing Computer, In: Communication of the ACM, Vol. 48, No. 3 (2005)

[38] Shneiderman, Ben; Designing the User Interface, Strategy for Effective Human-Computer Interface, Addison Wesley, 1992

[39] Prometeus: New Applications for Ubiquitous Learning. Prometeus Position Paper, http://prometeus.org, accessed June 2005, (2001).

[40] Ogata, H.; Yin, C.; Yano, Y.: Context-Aware Support for Learning Japanese Polite Expressions. In: Proceedings of the IEEE International Workshop on Wireless and Mobile Technologies in Education, WMTE'04, (2004). https://doi.org/10.1109/wmte.2005.68

[41] Hsi, S.: The Electronic Guidebook: A Study of User Experiences using Mobile Web Content in a Museum. In: Proceedings of the IEEE International Workshop on Wireless and Mobile Technologies in Education, WMTE'02, (2002). https://doi.org/10.1109 /wmte.2002.1039220

\section{$7 \quad$ Authors}

Muhammad Ashar, born in PARE PARE, 1973. We graduated from doctoral programs at NAIST Japan, Ubiquitous computing systems, 2016. We are one of the lecturers in Informatics Engineering, Faculty of Engineering, State University of Malang, Malang, Indonesia, since 2008. His research interests is in the field of Ubiquitous and Electrical Engineering. We have published several articles in national or international journals.

Harits Ar Rosyid, is one of the lecturers in Informatics Engineering Education, Faculty of Engineering, Malang State University, Malang, Indonesia, since 2010.

Agusta Rahmat Taufani, Faculty, is one of the lecturers in higher education in the Department of Electrical Engineering, Faculty of Engineering, State University of Malang, Malang, Indonesia, since 2012.

Khaidir Rahman Nasir was born in Maros, 1989. graduated from a Masters in Makassar State University in 2015. We are one of the lecturers in the Department of Informatics, Faculty of Engineering, STMIK AKBA, South Sulawesi, Indonesia, since 2014. His research interests are in the field of informatics engineering and Vocational education. has published several articles in national or international journals. ORCID 0000-0003-4601-4056.

Article submitted 2020-05-15. Resubmitted 2020-06-26. Final acceptance 2020-06-27. Final version published as submitted by the authors. 